\title{
Synthesis and photoelectrochemical characterization of a high molar extinction coefficient heteroleptic ruthenium(II) complex
}

\author{
L GIRIBABU $^{\mathrm{a}, *}$, VARUN KUMAR SINGH ${ }^{\mathrm{a}}$, M SRINIVASU $^{\mathrm{a}}$, CH VIJAY KUMAR ${ }^{\mathrm{a}}$, \\ $V_{\text {GOPAL REDDY }}^{\mathrm{b}}$, Y SOUJNYA ${ }^{\mathrm{c}}$ and P YELLA REDDY ${ }^{\mathrm{b}}$ \\ ${ }^{a}$ Nanomaterials Laboratory, Inorganic and Physical Chemistry Division, Indian Institute \\ of Chemical Technology, Hyderabad 500 607, India \\ ${ }^{\mathrm{b}}$ Aisin Cosmos R\&D Co. Ltd. HUDA Complex, Tarnaka, Hyderabad 500 007, India \\ ${ }^{\mathrm{c}}$ Molecular Modelling Group, Indian Institute of Chemical Technology, Hyderabad 500 607, India \\ e-mail: giribabu@iict.res.in
}

MS received 12 November 2010; revised 7 April 2011; accepted 17 May 2011

\begin{abstract}
A new high molar extinction coefficient heteroleptic ruthenium(II) complex (m-BL-1) that contains a 4,4'4'"-tricaboxy-2,2':6',2'-terpyridine, 4,4'-bis-[3,5-di-tert-butyl-phenyl)-vinyl]-[2,2']bipyridyl and a thiocyanate ligand in its molecular structure has been synthesized and completely characterized by CHN, Mass, ${ }^{1} \mathrm{H}-\mathrm{NMR}$, UV-Vis, and fluorescence spectroscopies as well as cyclic voltammetry. The new sensitizer was tested in dye-sensitized solar cells using three different redox electrolytes and compared its performance to that of standard sensitizer black dye.
\end{abstract}

Keywords. Dye-sensitized solar cells; extended $\pi$-conjugation; terpyridine; heteroleptic; redox electrolyte.

\section{Introduction}

The supply and demand of energy has been considered as the most significant problem which the human life will face in next generation leading to increased interest and demand for renewable energy sources. ${ }^{1}$ One of the promising candidates for them is solar energy that is renewable, clean, and an inexhaustible source. In this regard, mesoscopic dye-sensitized solar cells (DSSC) have attracted considerable attention for the last two decades because of their high photon-to-electricity conversion efficiency, low-cost and easy to fabricate over the conventional $p-n$ solid state devices. ${ }^{2-4}$ In these devices, the sensitizer is one of the key components for high efficiency and durability. The polypyridyl ruthenium(II) complex-based dyes are one of the most widely studied efficient charge transfer photosensitizers, owing to their broad and strongly absorbing metal-to-ligand chargetransfer (MLCT) absorption bands, chemical stability of photoexcited states, and oxidized form. ${ }^{5-7}$ The paradigms include bis(tetrabutylammonium)-cis-di(thiocyanato)$N, N^{\prime}$-bis (4-carboxylato-4'-carboxylic acid-2,2'-bipyridine) ruthenium(II) (the $\mathbf{N 7 1 9}$ dye), and trithiocyanato 4,4'4"-tricaboxy-2,2':6',2"-terpyridine ruthenium(II) (the

\footnotetext{
${ }^{*}$ For correspondence
}

black dye), yields conversion efficiencies of up to $12 \% .^{8-10}$ Although the -NCS groups greatly contribute to absorption domain widening by an additional electronic transition process, they also exhibit instability when the dye is in its oxidized form. For this reason, the devices based on black dye have shown less durability though efficiency is better than $\mathbf{N 7 1 9}$ sensitizer. In order to further improve the device stability based on N719 and black dye, one has to replace -NCS groups with other ligands. Bignozzi and co-workers and Gratzel et al. have demonstrated the dramatic alteration of performance and durability by replacing -NCS groups with $-\mathrm{CN}$ in $\mathbf{N 7 1 9}$ sensitizer. ${ }^{11-13}$ Nazeeruddin et al. have reported cyclometallated ruthenium complexes (both -NCS ligands in $\mathbf{N 7 1 9}$ replaced by a phenylpyridine ligand) with efficiency $>10 \% .^{14}$ These molecules have shown improved performance in DSSC test cell devices. Recently, our group has replaced two of -NCS ligands with bipyridine ligand with reasonably good efficiency. ${ }^{15}$

Here, we report a new heteroleptic ruthenium(II) polypyridyl complex having a terpyridine ligand and a bipyridine ligand in its molecular structure (m-BL-1). The two -NCS groups in black dye are replaced by a bipyridine ligand. The bipyridine ligand having an electron releasing group 3,5-di-tert-butyl phenyl groups on extended- $\pi$ conjugation (HRD-1 ligand). The presence 

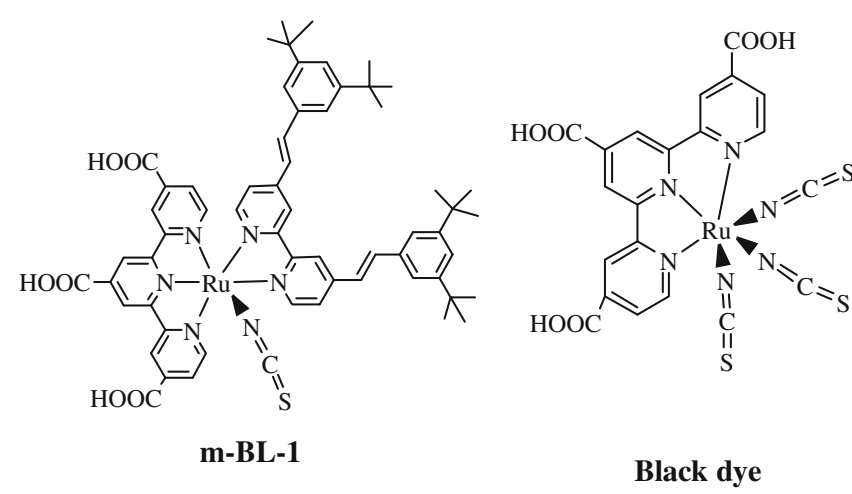

Figure 1. Molecular structure of m-BL-1 and black dye.

of extended- $\pi$ conjugation in its molecules increases the molar absorption coefficient. ${ }^{16,17}$ The reason to choose the HRD-1 ligand in m-BL-1, in its ruthenium(II) polypyridyl complex is that it has shown good durability.$^{18}$ The anchoring carboxyl groups are present on terpyridine ligand. The molecular structure of m-BL-1 is shown in figure 1 . The new sensitizer m-BL-1 was tested in DSSC devices using three different redox electrolytes and compared its performance to that of standard sensitizer black dye.

\section{Experimental}

The chemicals and solvents utilized in this study were purchased from either Aldrich Chemical Co. (U.S.A) or Ranbaxy (India). The solvents utilized for spectroscopic and electrochemical experiments were further purified using the standard procedures. ${ }^{19}$ The compounds [2,2',6'2']Terpyridine-4,4',4"-tricaboxylic acid trimethyl ester and 4,4'-bis-[3,5-di-tert-butyl-phenyl)vinyl]-[2,2']bipyridyl and black dye were synthesized according to the procedures as reported in the literature. ${ }^{9,18}$

\subsection{Synthesis of $m-B L-1$}

$\mathrm{RuCl}_{3} .3 \mathrm{H}_{2} \mathrm{O}(624 \mathrm{mg}, 2.5 \mathrm{mmol})$ was dissolved in a mixture of ethanol and chloroform $(100 \mathrm{ml})$. To this $1.00 \mathrm{~g}(2.5 \mathrm{mmol})$ of [2,2',6'2']-terpyridine-4,4',4"'tricaboxylic acid trimethyl ester was added and the reaction mixture was refluxed under nitrogen atmosphere. The progress of the reaction was monitored by UV-Vis., spectroscopy. After $4 \mathrm{~h}$ the solvent was removed under reduced pressure and the crude compound was dried under vacuum to get the trichloro derivative of ruthenium complex.
The trichloro derivative of ruthenium complex ( $200 \mathrm{mg}, 0.32 \mathrm{mmol}$ ) was dissolved in $100 \mathrm{ml}$ of dry DMF. To this, $228 \mathrm{mg}(0.39 \mathrm{mmol})$ of 4,4'-bis-[3,5di-tert-butyl-phenyl)-vinyl]-[2,2']bipyridyl was added and reaction mixture was refluxed for $4 \mathrm{~h}$ under nitrogen atmosphere. The reaction mixture was cooled to $80^{\circ} \mathrm{C}$ and aqueous solution of ammonium thiocyanate (760 mg, $9.92 \mathrm{mmol}$ ) was added and refluxed for further $2 \mathrm{~h}$. The reaction mixture was further cooled to room temperature and triethyl amine and water $(2+2 \mathrm{ml})$ were added and then refluxed for $48 \mathrm{~h}$. Then the solvent was removed under reduced pressure and water was added to get the precipitate. The solid precipitate was filtered, washed with water and dried under vacuum. The obtained solid material was dissolved in methanol, which contains TBA (tetrabutyl ammonium hydroxide) and submitted to sephadex LH-20 column chromatography with methanol as eluent. The main intense brown colour band was collected and solvent was removed under reduced pressure to get the desired compound. m-BL-1: Anal. calcd. for $\mathrm{C}_{61} \mathrm{H}_{63} \mathrm{~N}_{6} \mathrm{O}_{6} \mathrm{RuS}$ : C, 66.04; H, 5.72; N, 7.58 Found: C, 66.00; H, 5.65; N, 7.50\%. MS: m/z+1TBA 1351. ${ }^{1} \mathrm{H}$ NMR $\left(\mathrm{CD}_{3} \mathrm{OD}\right)(300 \mathrm{MHz})$ $\delta$ ppm: 9.08 (dd, $4 \mathrm{H}, J=4.6 \mathrm{~Hz}), 8.80(\mathrm{~s}, 2 \mathrm{H}), 8.70(\mathrm{~d}$, $2 \mathrm{H}, J=4.5 \mathrm{~Hz}), 8.65(\mathrm{~s}, 2 \mathrm{H}), 7.70(\mathrm{~d}, 2 \mathrm{H}, J=4.0)$, $7.25(\mathrm{~d}, 2 \mathrm{H}, \mathrm{J}=3.8 \mathrm{~Hz}), 7.20(\mathrm{~s}, 2 \mathrm{H}), 7.13(\mathrm{~s}, 4 \mathrm{H}), 7.10$ $(\mathrm{d}, 2 \mathrm{H}, \mathrm{J}=6.2 \mathrm{~Hz}), 6.95(\mathrm{~d}, 2 \mathrm{H}, J=6.2 \mathrm{~Hz}), 1.35$ (m, 36H). UV-Vis., in ethanol $\left(\lambda_{\max }, \varepsilon \mathrm{M}^{-1} \mathrm{~cm}^{-1}\right): 510$ $(17,300)$.

\subsection{Methods}

The UV-Vis spectra were recorded with a Shimadzu model 1700 spectrophotometer. Steady state fluorescence spectra were recorded using a Spex model Fluoromax-3 spectrofluorometer. ${ }^{1} \mathrm{H}$ NMR spectra were obtained at $300 \mathrm{MHz}$ using a Brucker 300 Avance NMR spectrometer running X-WIN NMR software. The chemical shifts are relative to tetramethylsilane (TMS). The Fourier transform IR (FTIR) spectra of all the samples were measured using a Thermo Nicolet Nexus 670 spectrometer. Cyclic- and differential pulse voltammetric measurements were performed on a PC-controlled $\mathrm{CH}$ instruments model $\mathrm{CHI}$ 620 electrochemical analyzer. Cyclic voltammetric experiments were performed on $1 \mathrm{mM}$ dye solution in acetonitrile at scan rate of $100 \mathrm{mV} / \mathrm{s}$ using $0.1 \mathrm{M}$ tetrabutyl ammoniumperchlorate (TBAP) as supporting electrolyte. The working electrode is glassy carbon, standard calomel electrode (SCE) is reference electrode and plantinum wire is an auxillary electrode. After a cyclic voltammogram (CV) had been recorded, ferrocene was added, and 
a second voltammogram was measured. Thermogravimetric measurements were carried out on a Mettler Toledo TGA/SDTA 851e instrument heating rate at

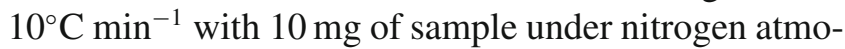
sphere. DFT calculations were done for the ground state optimization of m-BL-1 using Gaussian 03. ${ }^{20}$

\subsection{Test cell preparation and photoelectrical measurements}

The detailed $\mathrm{TiO}_{2}$ photoelectrode (area: ca. $0.740 \mathrm{~cm}^{2}$ ) preparation was described in our earlier studies. ${ }^{21-23}$ Briefly, A $8 \mu \mathrm{m}$ thick film of $19-\mathrm{nm}$ sized $\mathrm{TiO}_{2}$ particles was first screen-printed on a fluorine-doped $\mathrm{SnO}_{2}$ (FTO) conducting glass electrode, and a $4 \mu \mathrm{m}$ thick second layer of $400 \mathrm{~nm}$ sized light scattering anatase particles were subsequently coated onto the first one. The $\mathrm{TiO}_{2}$ electrodes were gradually heated under an air flow at $500^{\circ} \mathrm{C}$ for $30 \mathrm{~min}$. followed by treatment with $\mathrm{TiCl}_{4}$ and sintered at $500^{\circ} \mathrm{C}$ for $20 \mathrm{~min}$. The $\mathrm{TiO}_{2}$ electrodes were then immersed into the dye solutions $(0.3 \mathrm{mM}$ in ethanol) and then soaked at room temperature for $16 \mathrm{~h}$. A platinized FTO glass was used as counter electrode.

Photoelectrochemical data were obtained using a $450 \mathrm{~W}$ xenon light source focused to give $1000 \mathrm{~W} / \mathrm{m}^{2}$, the equivalent of one sun at AM 1.5 (the luminance of the lamp has normalized and corrected by the supplier), at the surface of the test cell. A sandwich cell was assembled by using the dye anchored $\mathrm{TiO}_{2}$ films as the working electrode and conducting glass (TEC-15; the glass had been coated with a fluorine-doped stan- nic oxide layer; sheet resistance, $10 \Omega /$ square) coated with chemically deposited platinum from $0.05 \mathrm{M}$ hexachloroplatinic acid as the counter electrode. The two electrodes were held to each other by heating with a hot-melt ionomer film (Surlyn 1702, $50 \mu \mathrm{m}$ thickness, Du-Pont) as a spacer between the electrodes. A drop of electrolyte solution was placed on the drilled hole in the counter electrode (which had already made) and was driven into the cell via vacuum backfilling. Finally, the hole was sealed using additional Bynel $(35 \mu \mathrm{m})$ and a cover glass $(0.1 \mathrm{~mm}$ thickness). We have used three different redox electrolytes in this study and the composition of redox electrolytes are E-01: $0.05 \mathrm{M}$ I2, 0.1 M LiI, 0.6 M 1,2-dimethyl-3$n$-propylimidazolium iodide (DMPI), $0.5 \mathrm{M}$ tert-butyl pyridine in acetonitrile solvent. Ei-301: $1.0 \mathrm{M} \mathrm{LiI,}$ $0.05 \mathrm{M} \mathrm{I}_{2} \gamma$-butyrolactone. EA-10: $0.1 \mathrm{M} \mathrm{I}_{2}, 0.6 \mathrm{M}$ DMPI and $0.5 \mathrm{M} n$-methylbenzimidazolium iodide (NMBI) in $\gamma$-butyrolactone solvent.

\section{Results and discussions}

\subsection{Synthesis}

The ligand 4,4'-bis-[3,5-di-tert-butyl-phenyl)-vinyl][2,2']bipyridyl (HRD-1 ligand) was synthesized as per the literature methods. ${ }^{18}$ The complex m-BL-1 was synthesized according to the scheme 1 and purified using sephadex column with methanol as eluent. The complex m-BL-1 was completely characterized by CHN, IR, Mass, UV-Vis., fluorescence spectroscopies

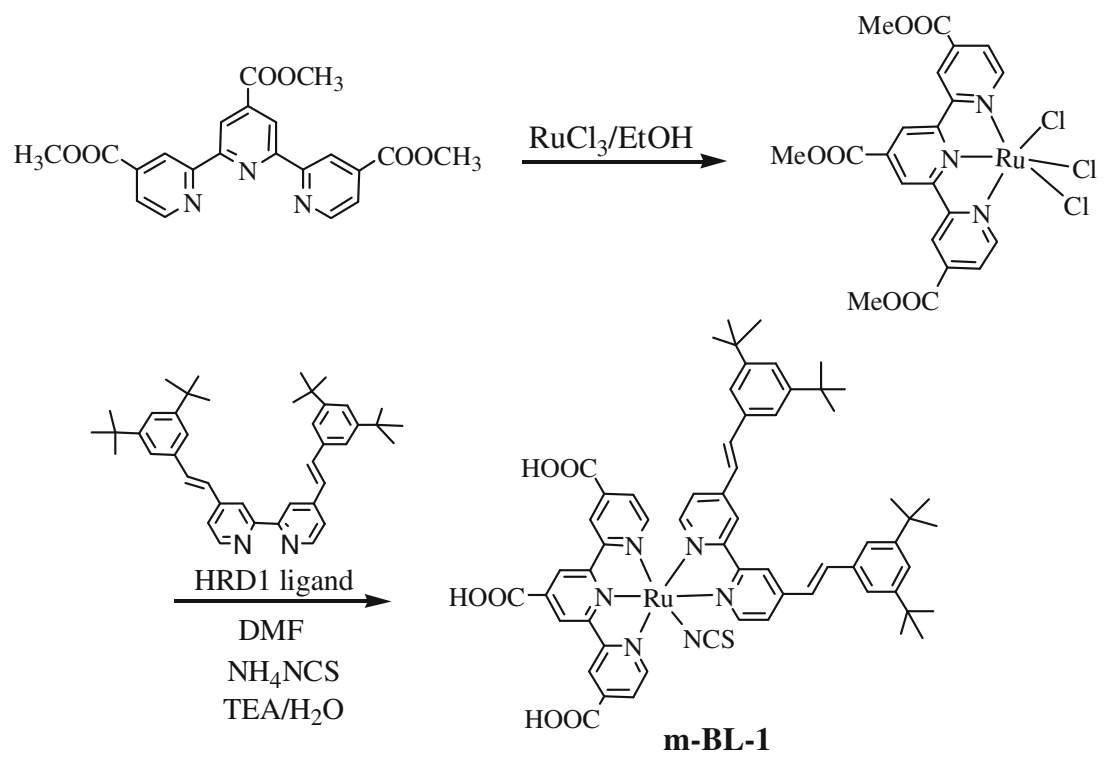

Scheme 1. Synthesis of m-BL-1 dye. 


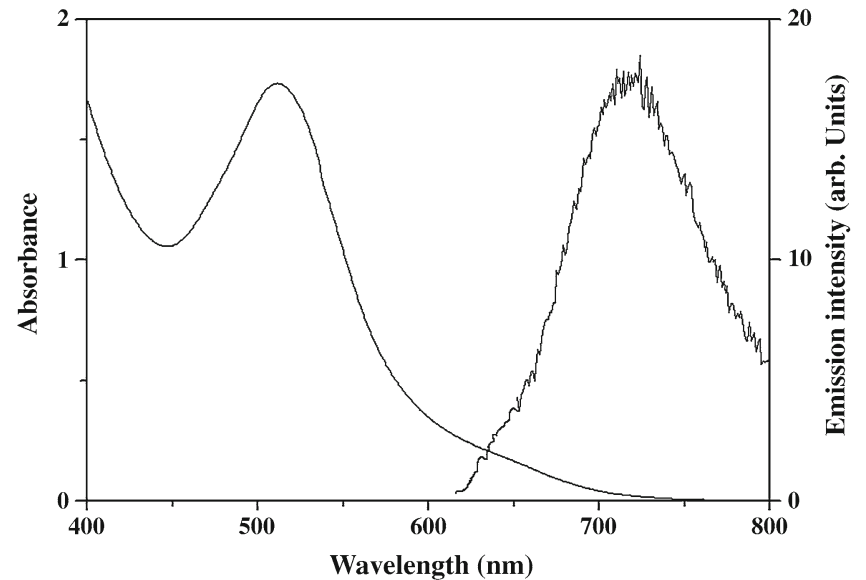

Figure 2. Electronic absorption and emission spectra of m-BL-1 in ethanol solvent.

as well as cyclic voltammetry. The mass spectrum of m-BL-1 consists of a peak at $1351 \mathrm{~m} / \mathrm{z}$, which corresponds to the presence of one TBA molecule in its molecular structure.

Figure 2 displayed the absorption spectrum of $\mathbf{m}-\mathbf{B L}-\mathbf{1}$ in ethanol and the corresponding data were presented in table 1 . The metal to ligand charge transfer transition (MLCT) of $\mathbf{m}-\mathbf{B L}-1$ was centered at $510 \mathrm{~nm}$ with molar extinction coefficient $(\varepsilon)$ of $17,300 \mathrm{M}^{-1} \mathrm{~cm}^{-1}$. In contrast, black dye has MLCT absorption maximum at $619 \mathrm{~nm}$ with $\varepsilon$ of $7,987 \mathrm{M}^{-1} \mathrm{~cm}^{-1} .{ }^{9}$ The absorption maximum was bathochromic shifted in the case of m-BL-1, due to the replacement of two -NCS ligands with an ancillary bipyridine ligand. The $\varepsilon$ value of m-BL-1 has increased double when compared to that of standard sensitizer, black dye. This is due to the presence of extended- $\pi$ conjugation on the ancillary bipyridine ligand of $\mathbf{m}-\mathbf{B L}-\mathbf{1}$ complex. It is known from the literature that the presence of extended- $\pi$ conjugation enhances $\varepsilon$ of the complex. ${ }^{17,24}$ Intraligand $\pi-\pi *$ transitions of terpyridine ligand are located at $320 \mathrm{~nm}$, while that of bipyridine is at $280 \mathrm{~nm}$. The absorption features of m-BL-1 adsorbed on an opaque $\mathrm{TiO}_{2}$ film $(8 \mu \mathrm{m}$ thick) was similar to that of observed in solution except for a slight red shift in absorption maxima due to interaction of anchoring groups to the nanocrystalline $\mathrm{TiO}_{2}$ surface. Figure 2 also depicts the emission spectrum of m-BL-1. Excitation of lower energy MLCT transition of $\mathbf{m}-\mathbf{B L}-1$ in ethanol solvent at room temperature produces an emission centered at $720 \mathrm{~nm}$. From the absorption and emission spectra, the singlet state $\left(\mathrm{E}_{0-0}\right)$ energy of m-BL-1 and black dye 1.94 and $1.60 \mathrm{eV}$, respectively. Quenched emission spectrum of m-BL-1 was observed when adsorbed on $8 \mu \mathrm{m}$ thick nanocrystalline $\mathrm{TiO}_{2}$ layer, as a consequence of electron injection from the excited state of $\mathrm{Ru}(\mathrm{II})$ complex to the conduction band of $\mathrm{TiO}_{2}$.

The redox potentials of $\mathbf{m}-\mathbf{B L}-\mathbf{1}$ was evaluated by using cyclic and differential pulse voltammetric techniques in DMF solvent with $0.1 \mathrm{M}$ tetrabutyl ammonium perchlorate as supporting electrolyte and compared their data with that of the standard sensitizer black dye in table 1. From the table it is clear that m-BL-1 undergoes one electron reversible oxidation at $0.78 \mathrm{~V}$ vs. SCE. The oxidation process can be readily assigned to the $\mathrm{Ru}(\mathrm{II}) / \mathrm{Ru}(\mathrm{III})$ redox couple. It also undergoes two reductions at -1.33 and $1.70 \mathrm{~V}$, corresponding to the reduction of terpyridine acid and ancillary bipyridine ligands. The excited oxidation potential of $\mathbf{m}-\mathbf{B L}-1$ is $1.16 \mathrm{~V}$, which is above the conduction band of $\mathrm{TiO}_{2}{ }^{25}$

To know the electronic distribution of $\mathbf{m}-\mathbf{B L}-\mathbf{1}$ sensitizer, we performed DFT calculations of the electronic ground state of $\mathbf{m}-\mathbf{B L}-1$ sensitizer using mPW1PW91 method for the geometry optimization with LANL2DZ basis function on $\mathrm{Ru}$ and $6-31 \mathrm{~g}(\mathrm{~d})$ basis function on $\mathrm{C}, \mathrm{H}, \mathrm{N}, \mathrm{O}$ and $\mathrm{S}$. As can be seen from the figure 3, HOMO, HOMO-1 and HOMO-2, is the electron delocalized over the $\mathrm{Ru}(\mathrm{II})$ metal and -NCS ligand. The $\mathrm{LUMO}, \mathrm{LUMO}+1$ and LUMO +2 are $\pi^{*}$ orbitals delocalized over the terpyridine carboxylic acid ligand facilitating electron injection from the excited state of $\mathbf{m}$ BL-1 sensitizer to the conduction band of $\mathrm{TiO}_{2}$. These results are in good agreement with other ruthenium(II) polypyridyl complexes reported in the literature. ${ }^{26}$

Table 1. UV-Visible, emission and electrochemical data.

\begin{tabular}{|c|c|c|c|c|c|c|c|}
\hline \multirow[t]{2}{*}{ Sensitizer } & \multirow[t]{2}{*}{$\lambda_{\max }, \mathrm{nm}, \varepsilon\left(\mathrm{mol}^{-1} \mathrm{~cm}^{-1}\right)^{\mathrm{a}}$} & \multirow[t]{2}{*}{$\lambda_{\mathrm{em}}, \mathrm{nm}^{\mathrm{b}}$} & \multicolumn{2}{|c|}{$\underline{\mathrm{E}_{1 / 2} \mathrm{~V} \text { vs. } \mathrm{SCE}^{\mathrm{c}}}$} & & \multirow[t]{2}{*}{$\mathrm{E}_{0-0}, \mathrm{eV}^{\mathrm{d}}$} & \multirow[t]{2}{*}{$\mathrm{E}_{\mathrm{ox}}^{*}$} \\
\hline & & & $\mathrm{Ox}$ & Red & & & \\
\hline Black Dye $^{\mathrm{e}}$ & $619(7,987)$ & 850 & 0.60 & -1.10 & -1.20 & 1.60 & -1.00 \\
\hline m-BL-1 & $510(17,300)$ & 720 & 0.78 & -1.33 & -1.70 & 1.94 & -1.16 \\
\hline
\end{tabular}

${ }^{\mathrm{a}}$ Solvent: ethanol, error limits: $\lambda_{\max }, \pm 1 \mathrm{~nm}, \varepsilon \pm 10 \%$. ${ }^{\mathrm{b}}$ Solvent: ethanol, $\lambda_{\max }, \pm 1 \mathrm{~nm}$. ${ }^{\mathrm{c}}$ Solvent: DMF, error limits: $\mathrm{E}_{1 / 2} \pm$ $0.03 \mathrm{~V}, 0.1 \mathrm{M}$ TBAP. ${ }^{\mathrm{d}}$ Error limits: $0.05 \mathrm{eV}$. ${ }^{\mathrm{e}}$ From the reference no. ${ }^{9}$ 
HOMO

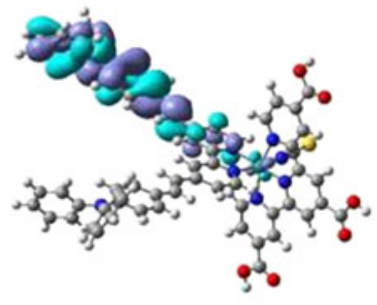

LUMO

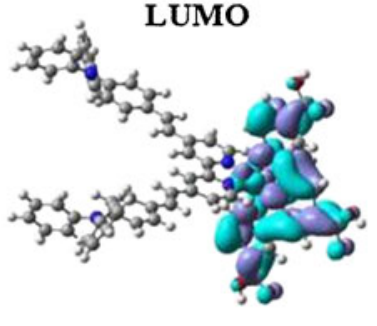

HOMO-1

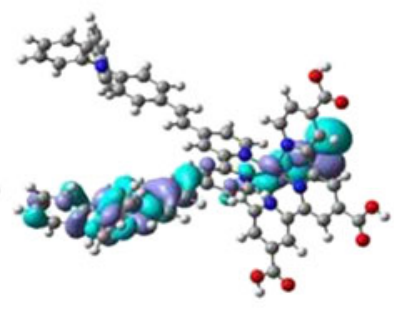

LUMO+1

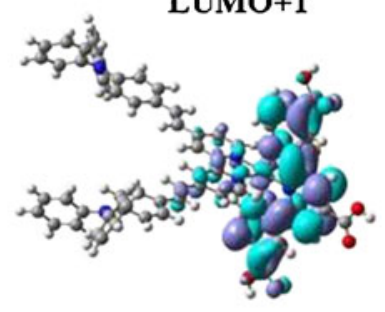

HOMO-2

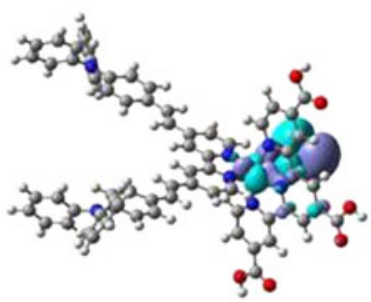

LUMO+2

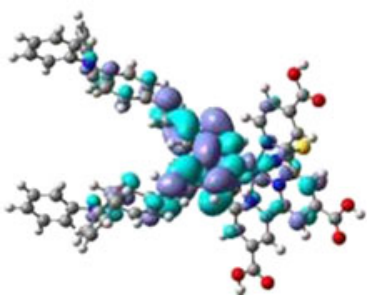

Figure 3. Molecular orbital spatial orientation of m-BL-1.

\subsection{Photovoltaic measurements}

The performance of newly synthesized $\mathbf{m - B L - 1}$ as a sensitizer with a sandwitch type nanoscrystalline $\mathrm{TiO}_{2}$ was determined from measurements on photovoltaic cells using three different redox electrolytes i.e., E-01, Ei-301 and EA-10 and compared its performance with that of standard sensitizer black dye under similar test cell conditions. The photocurrent action spectra of both m-BL-1 and black dye in all three redox electrolytes were shown in figure 4 , where the incident monochromatic photon-to-current conversion efficiencies (IPCE) values are plotted as a function of excitation wavelength. The IPCE was calculated according to the following equation. ${ }^{27}$

$$
\operatorname{IPCE}(\%)=1240\left(J_{S C} / \lambda \phi\right) \times 100,
$$

where $\lambda$ is the wavelength (nm), $J_{S C}$ is the photocurrent density under short circuit conditions $\left(\mathrm{mA} / \mathrm{cm}^{2}\right)$ and $\phi$ is the incident radiative flux $\left(\mathrm{mW} / \mathrm{cm}^{2}\right)$. We have observed IPCE values of 55, 84 and $35 \%$ at $520 \mathrm{~nm}$ using E-01, Ei-301 and EA-10, and respectively using m-BL-1 as sensitizer. Under similar test cell conditions using black dye as sensitizer, we have observed IPCE value of 37, 73 and $9 \%$ at $627 \mathrm{~nm}$ with E-01, Ei-301 and EA-10, respectively. Therefore, it is clear that DSSC devices using $\mathbf{~ m - B L - 1}$ sensitizer has shown better IPCE values than black dye. From the figure 4, it is clear that the photocurrent action spectrum resembles the absorption spectra except for a slight red shift by $c a .10 \mathrm{~nm}$ in both m-BL-1 and black dye. The photoresponse of thin films displays a broad spectral response covering the entire visible spectrum up to $850 \mathrm{~nm}$ in case of $\mathbf{m - B L}-\mathbf{1}$ and up to $950 \mathrm{~nm}$ in case of black dye.
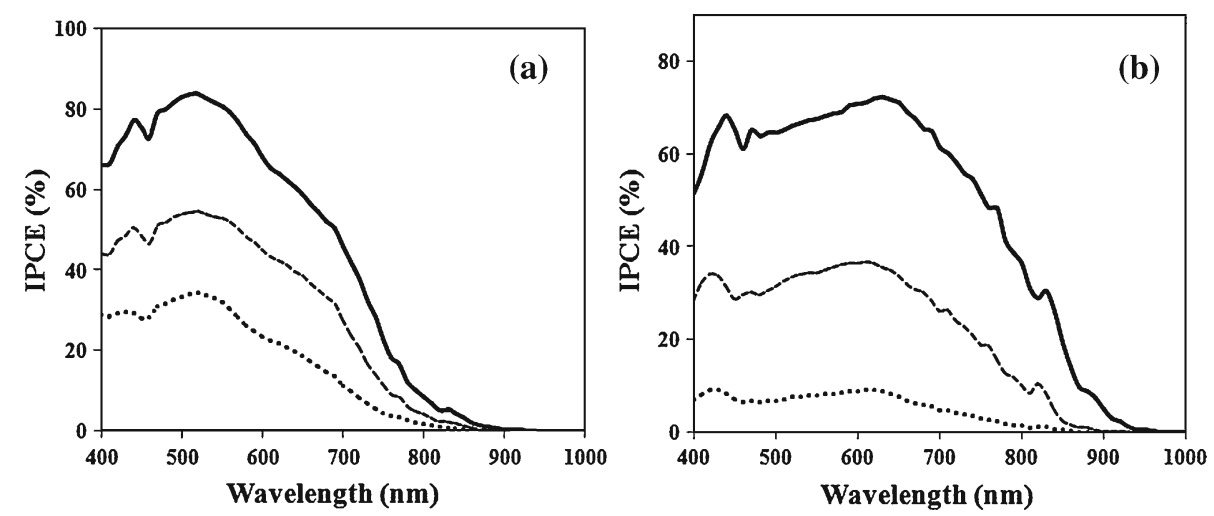

Figure 4. Photocurrent action spectra of (a) m-BL-1 and (b) black dye using ( - ) Ei-301, (----) E-01 and (......) EA-10 redox electrolytes. 

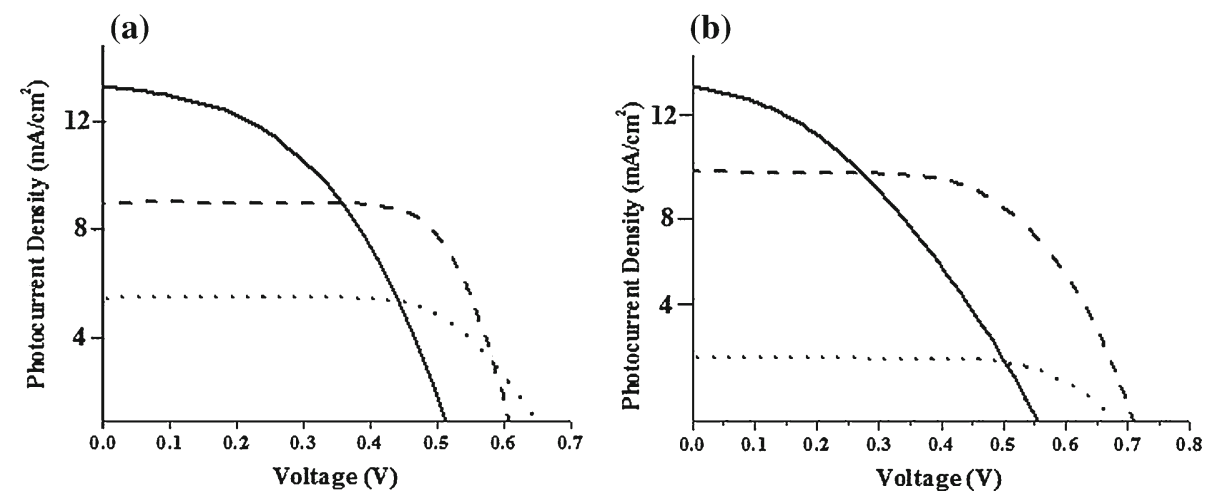

Figure 5. Photocurrent action spectra of (a) m-BL-1 \& (b) black dye using ( - ) Ei-301, (----) E-01 and (..... E) EA-10 redox electrolytes.

Figure 5 shows the photocurrent-voltage characteristics of $\mathbf{m}-\mathbf{B L}-\mathbf{1}$ and black dye in all three different redox electrolytes under 1.0 sun irradiation $\left(1000 \mathrm{~W} / \mathrm{m}^{2}\right)$ and corresponding data are shown in table 2. The solar energy-to-electricity conversion efficiency $(\eta)$, under white-light irradiation can be obtained from the following equation.

$$
\eta[\%]=\frac{J_{S C}\left[A m^{-2}\right] \cdot V_{O C}[\mathrm{~V}] X f f}{I_{0}\left[\mathrm{Wm}^{-2}\right]} \times 100,
$$

where $I_{0}$ is the photon flux (e.g., $1000 \mathrm{~W} \mathrm{~m}^{-2}$ for $1.0 \mathrm{sun}), J_{\mathrm{SC}}$ is the short-circuit photocurrent density under irradiation, $V_{\mathrm{OC}}$ is the open-circuit voltage, and $f f$ represents the fill factor. We have observed an overall conversion efficiency of $3.72 \%$ under 1.0 sun irradiation $\left(J_{S C}=8.56 \mathrm{~mA} / \mathrm{cm}^{2}, V_{O C}=610 \mathrm{mV}\right.$, ff $=$ 0.72) using E01 redox electrolytes. Under similar test cell conditions black dye has shown $\eta$ of $4.47 \%\left(J_{S C}=\right.$ $10.04 \mathrm{~mA} / \mathrm{cm}^{2}, V_{O C}=710 \mathrm{mV}$, ff $=0.61$ ). The solvent used in this redox electrolyte is acetonitrile, which is highly volatile and as a result the durability of the device will be low. To overcome these problems, we have used $\gamma$-butyrolactone solvent in Ei-301 and EA-10 redox electrolytes. The reason for using $\gamma$ butyrolactone lies in its high boiling point, low volatility, non-toxic and good photochemical stability, making it viable for practical applications. Using EA-10 redox electrolyte with m-BL-1 sensitizer, we have observed $\eta$ of $2.13 \%\left(J_{S C}=4.82 \mathrm{~mA} / \mathrm{cm}^{2}, V_{O C}=650 \mathrm{mV}\right.$, $\mathrm{ff}=0.68)$. Under similar test cell conditions, black dye has shown $\eta$ of $1.20 \%\left(J_{S C}=2.57 \mathrm{~mA} / \mathrm{cm}^{2}, V_{O C}=\right.$ $680 \mathrm{mV}, \mathrm{ff}=0.68$ ). The low efficiency of test cell devices using EA-10 redox electrolyte in both the sensitizers are due to the high viscose nature of $\gamma$ butyrolactone solvent and unable to penetrate into the pores of nanocrystalline $\mathrm{TiO}_{2}$. In order to further improve the efficiency of test cell devices, we have modified the redox electrolyte composition keeping the solvent same. We have used excess LiI in Ei-301 redox electrolyte. The presence of excess concentration LiI, decreases $V_{O C}$ due to positive shift of band edge but increases electron transport property and acts as the driving force for electron injection. ${ }^{28}$ From the table 2, it is clear in both the sensitizers, $V_{O C}$ reduced by $15 \%$

Table 2. Photovoltaic performance of m-BL-1 and black dye. ${ }^{\text {a }}$

\begin{tabular}{lccccc}
\hline Sensitizer & Electrolyte $^{\mathrm{b}}$ & $J_{S C}\left(\mathrm{~mA} / \mathrm{cm}^{2}\right)^{\mathrm{c}}$ & $V_{O C}(\mathrm{mV})^{\mathrm{c}}$ & $\mathrm{ff}^{\mathrm{c}}$ & $\eta(\%)$ \\
\hline m-BL-1 & $\mathbf{E 0 1}$ & 8.56 & 610 & 0.72 & 3.76 \\
& Ei-301 & 13.11 & 510 & 0.46 & 3.11 \\
Back Dye & $\mathbf{E A 1 0}$ & 4.82 & 650 & 0.68 & 2.13 \\
& E01 & 10.04 & 710 & 0.61 & 4.47 \\
& Ei-301 & 15.88 & 560 & 0.37 & 3.29 \\
& $\mathbf{E A 1 0}$ & 2.57 & 680 & 0.68 & 1.20 \\
\hline
\end{tabular}

aphotoelectrode: $\mathrm{TiO}_{2}\left(8+4 \mu \mathrm{m}\right.$ and $\left.0.74 \mathrm{~cm}^{2}\right)$; ${ }^{\mathrm{b}}$ electrolyte: E-01: $0.05 \mathrm{M} \mathrm{I}, 0.1 \mathrm{M}$ LiI, $0.6 \mathrm{M}$ 1,2-dimethyl-3- $n$ propylimidazolium iodide (DMPI), $0.5 \mathrm{M}$ tert-butyl pyridine in acetonitrile solvent. Ei-301: $1.0 \mathrm{M} \mathrm{LiI,} 0.05 \mathrm{M} \mathrm{I} 2 \gamma-$ butyrolactone. EA-10: 0.1 $\mathrm{M} \mathrm{I}_{2}, 0.6 \mathrm{M}$ DMPI and $0.5 \mathrm{M} n$-methylbenzimidazolium iodide (NMBI) in $\gamma$-butyrolactone. ${ }^{\mathrm{c}}$ Error limits: $J_{S C}: \pm 0.20 \mathrm{~mA} / \mathrm{cm}^{2}, V_{O C}= \pm 30 \mathrm{mV}, \mathrm{ff}= \pm 0.03$ 


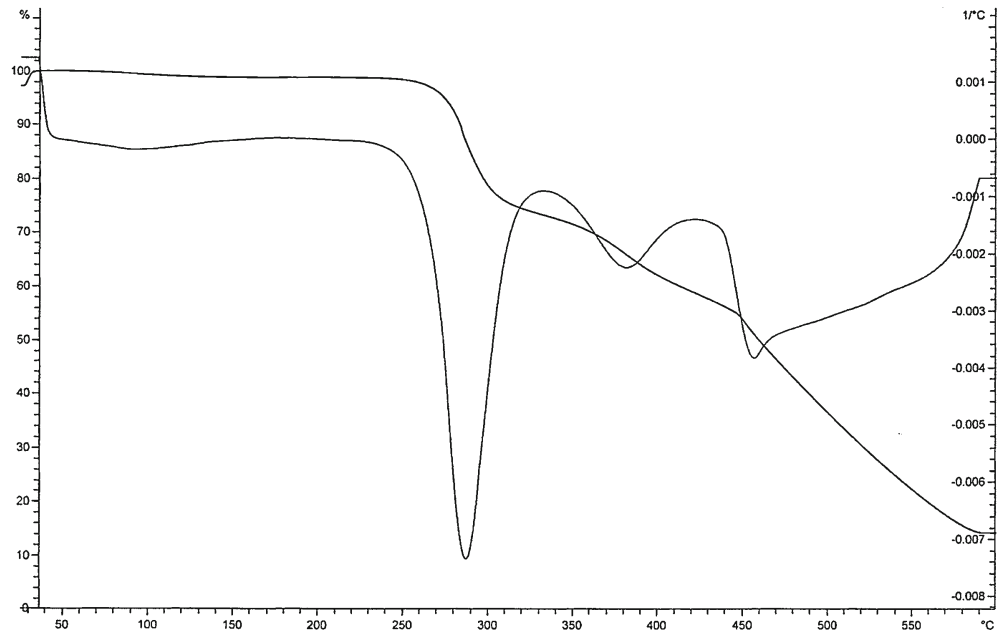

Figure 6. TG/DTG curves of $\mathbf{m}-\mathbf{B L}-1$ with heating rate of $10^{\circ} \mathrm{C} \mathrm{min}^{-1}$ under nitrogen.

with an increase of $J_{S C}$. As a result the efficiency is also increased in both the sensitizers. We have observed better efficiency using $\mathbf{m}-\mathbf{B L}-\mathbf{1}$ sensitizer with EA-10 redox electrolyte than black dye based devices. In contrast, with the two other redox electrolytes the efficiency is high with black dye than m-BL-1 sensitizer. This may be due to the absorption of black dye extends up to $950 \mathrm{~nm}$, whereas in m-BL-1 it extends only $850 \mathrm{~nm}$.

\subsection{Thermal stability}

In order to use outdoor applications of DSSC devices, the sensitizer should be stable to higher temperatures. For this reason, we have carried out the thermogravimetric analysis of m-BL-1 to understand the thermal stability of new sensitizer. From the figure 6, it is apparent that the thermal behaviour $\mathbf{m}-\mathbf{B L}-\mathbf{1}$ is stable up to $250^{\circ} \mathrm{C}$. Under similar conditions, black dye also stable up to $250^{\circ} \mathrm{C}$.

\section{Conclusion}

In conclusion, we have designed, synthesized and characterized a ruthenium(II) polypyridyl complex that contains a terpyridine, bipyridine and thiocyanate ligand in its molecular structure. The absorption, emission and cyclic voltammetric studies showed that the LUMO of the new complex above the conduction band of $\mathrm{TiO}_{2}$ and HOMO below the redox couple of $\mathrm{I}^{-} / \mathrm{I}_{3}^{-}$. The photoelectrochemical studies showed that $\mathbf{m}-\mathbf{B L}-\mathbf{1}$ has more efficiency than black dye using EA-10 redox electrolyte. Both $\mathbf{m}-\mathbf{B L}-\mathbf{1}$ and black dye are thermally stable up to $250^{\circ} \mathrm{C}$.

\section{Acknowledgements}

We thank Indian Institute of Chemical Technology (IICT)-Aisin Cosmos collaborative project for financial support. V K S and Ch V are thankful to Council of Scientific and Industrial Research (CSIR) for research fellowship.

\section{References}

1. Robertson N 2006 Angew Chem. Int. Ed. 452338

2. Martinez-Diaz M V, Torre G and Torres T 2010 Chem. Commun. 467090

3. Gratzel M 2009 Acc. Chem. Res. 111788

4. Bowers J W, Upadhyaya H M, Calnan R, Nakada T and Tiwari A N 2009 Prog. Photovoltaics: Research and Applications 17265

5. Chi Y and Chou P-T 2010 Chem. Soc. Rev. 39638

6. Lin H, Wang W, Liu Y, Li X and Li J 2009 Front. Mater. Sci. China 3345

7. Kong F T, Dai S Y and Wang K J 2007 Advances in Opto Electronics 200775384

8. O’Regan B and Grätzel M 1991 Nature 353737

9. Nazeeruddin M K, Kay A, Rodicio I, Humphry-Baker R, Muller E, Liska P, Valchopoulos N and Grätzel M 1993 J. Am. Chem. Soc. 1156382

10. Gratzel M 2001 Nature 414338

11. Argazzi R, Iha N Y M, Zabri H, Odobel F and Bignozzi C A 2004 Coord. Chem. Rev. 2481299

12. Caramori S, Cristino V, Boaretto R, Argazzi R, Bignozzi C A and Carki A D 2010 Int. J. Photoenergy 2010458614

13. Clifford J N, Palomares E, Nazeeruddin M K, Gratzel M and Durrant J R 2007 J. Phys. Chem. C 1116561

14. Karthikeyan C S, Wietasch H and Thelakkat M 2007 Adv. Mater. 191091

15. Giribabu L, Bessho T, Srinivasu M, Vijaykumar Ch, Soujanya Y, Reddy P Y, Reddy V G, Yum J-H, Gratzel M and Nazeeruddin M K 2011 Dalton Trans 404497 
16. Wang P, Zakeeruddin S M, Moser J E, Humphry-Baker R, Comete P, Aranyos V, Hagfeldt A, Nazeeruddin M K and Gratzel M 2004 Adv. Mater. 161806

17. Wang P, Klein C, Humphry-Baker R, Zakeeruddin S M and Gratzel M 2005 J. Am. Chem. Soc. 127808

18. Giribabu L, Vijaykumar Ch, Rao Ch S, Reddy V G, Reddy P Y, Chandrasekharam M and Soujanya Y 2009 Energy and Environ Sci. 2770

19. Armarego W L F and Chai C L L 2003 Purification of laboratory chemicals (Amsterdam: Elsevier)

20. Frisch M J, Trucks G W, Schlegel H B, Scuseria G E, Robb M A, Cheeseman J R, Montgomery J A, Vreven T, Kudin K N, Burant J C, Millam J M, Iyengar S S, Tomasi J, Barone V, Mennucci B, Cossi M, Scalmani G, Rega N, Petersson G A, Nakatsuji H, Hada M, Ehara M, Toyota K, Fukuda R, Hasegawa J, Ishida M, Nakajima T, Honda Y, Kitao O, Nakai H, Klene M, Li X, Knox J E, Hratchian H P, Cross J B, Adamo C, Jaramillo J, Gomperts R, Stratmann R E, Yazyev O, Austin A J, Cammi R, Pomelli C, Ochterski J W, Ayala P Y, Morokuma K, Voth G A, Salvador P, Dannenberg J J, Zakrzewski V G, Dapprich S, Daniels A D, Strain M C, Farkas O, Malick D K, Rabuck A D, Raghavachari K, Foresman J B, Ortiz, Cui J V Q, Baboul A G, Clifford S, Cioslowski J, Stefanov B B, Liu G,
Liashenko A, Piskorz P, Komaromi I, Martin R L, Fox D, Keith T, Al-Laham M A, Peng C Y, Nanayakkara A, Challacombe M, Gill P M W, Johnson B, Chen W, Wong M W, Gonzalez C and Pople J A 2004 Gaussian 03, revision D.01; Gaussian, Inc.: Wallingford, CT

21. Giribabu L, Vijaykumar Ch, Reddy P Y, Yum J-H, Gratzel M and Nazeeruddin M K 2009 J. Chem. Sci. 121 75

22. Giribabu L, Vijaykumar Ch, Reddy V G, Reddy P Y, Rao Ch S, Jang S-R, Yum J-H, Nazeeruddin M K and Gratzel M 2007 Solar Energy Materials and Solar Cells 911611

23. Giribabu L, Vijaykumar Ch and Reddy P Y $2006 J$. Porphyrins and Phthalocyanines 101007

24. Wang P, Klein C, Humphry-Baker R, Zakeeruddin S M and Gratzel M 2005 J. Am. Chem. Soc. 127808

25. Hagfeldt A, Gratzel M 1995 Chem. Rev. 9549

26. Nazeeruddin M K, Bessho T, Cevey L, Its S, Klein C, Angelis De F, Fantacci S, Comete P, Liska P, Imai H and Gratzel M 2007 J. Photochem. Photobiol. A:Chemistry 185331

27. Subramanian V 2007 Electrochemical Society Interface 1632

28. Koops S E, O'Regarn B C, Barnes P R F and Durrant J R 2009 J. Am. Chem. Soc. 1314808 